J. Clin. Chem. Clin. Biochem.

Vol. 14, 1976, pp. 479-483

\title{
An Improved UV-Spectrophotometric Method for Routine Barbiturate Monitoring
}

\author{
By Vera Jeremić \\ Neuropsychiatric Clinic, University of Novi Sad, 21000 Novi Sad, Yugoslavia
}

and Radojka Nikolić

Department for Chemistry, Medical Faculty, University of Novi Sad, 21000 Novi Sad, Yugoslavia

(Received October 13, 1975/July 8, 1976)

Summary: A simple, rapid, quantitative, low-cost UV-differential spectrophotometric method for the routine monitoring of phenobarbital in serum and cerebrospinal fluid is described. This method can also be used for monitoring methylphenobarbital (Phemiton) and primidone (Mysoline), since the major active metabolite of both drugs is phenobarbital. The basis for our procedure is Goldbaum's method (Anal. Chem., 24, 1604 (1952)). This method was improved with several modifications including a single extraction technique with dichloroethane, which has produced a very simple but still accurate method. The whole analysis takes less than 20 minutes. This procedure is accurate in the range from $1-100 \mathrm{mg} / 1$ of phenobarbital in serum or cerebrospinal fluid.

\section{Verbesserte UV-spektrophotometrische Methode zur routinemäßigen Kontrolle von Barbituratkonzentrationen}

Zusammenfassung: Eine einfache, schnelle, quantitative und billige UV-spektrophotometrische Differenzmethode zur routinemäßigen Kontrolle der Phenobarbital-Konzentration in Serum und Liquor wird beschrieben. Diese Methode kann auch zur Kontrolle der Konzentrationen von Methylphenobarbital (Phemiton) und Primidon (Mysoline) angewandt werden, da der Hauptmetabolit beider Pharmaka Phenobarbital ist. Grundlage für unser Verfahren ist die Methode von Goldbaum (Anal. Chem. 24, 1604 (1952)). Durch mehrfache Modifikation einschließlich Extraktion mit Dichlorethan wurde das Verfahren zu einer sehr einfachen, dennoch genauen Methode verbessert. Die gesamte Analyse dauert weniger als 20 Minuten. Das Verfahren ist genau im Bereich von $1-100 \mathrm{mg} / 1$ Phenobarbital in Serum oder Liquor.

\section{Introduction}

The primary goals in the utilization of serum anticonvulsant drug levels in the management of patients with seizure disorders are to achieve either a reduction in the toxic effects or an improvement in the therapeutic effect secondary to the administration of these drugs. There may be considerable variability in the serum anticonvulsant levels in patients receiving identical doses of drug under standardized conditions (1). Only when the time course of pharmacologic effects can be related quantitatively to the time course of drug concentrations in the serum will it be possible to develop the most rational dosage regimens for safe and effective therapy, and to make appropriate adjustments of dosage in accordance with individual differences in drug meta: bolism and response.
In this paper a simple spectrophotometric method for routine phenobarbital serum and cerebrospinal fluid level monitoring is described. Methylphenobarbital (Phemiton) is almost completely metabolized in man to phenobarbital (2). The present concept of primidone (Mysoline) metabolism in humans includes its conversion to two major metabolites, phenobarbital and phenylethylmalonamide (3). Therefore, the methylphenobarbital serum level, as well as the primidone serum level, can be determined as the derived-phenobarbital level.

\section{Materials and Methods}

Equipment

Double-beam UV-spectrophotometer UNICAM SP 1800 with recorder. Any other UV-spectrophotometer with or without 
recorder can be used. Semimicro silica cells. Separating funnels for extraction.

\section{Reagents}

Chemicals and solvents were of reagent-grade quality. Redistilled water was used. Dichloroethane was purified before use. For this purpose, $25 \mathrm{ml}$ of dichloroethane were washed with $10 \mathrm{ml}$ of $\mathrm{NaOH}(0.1 \mathrm{~mol} / \mathrm{l})$ for 3 minutes. The phases were allowed to separate and the organic (lower) layer was drained to another separating funnel and washed twice with $10 \mathrm{ml}$ of redistilled water. Washing with dilute alkali, than with water, is important especially when using chloroform or dichlorethane which decompose on standing. The decomposition products may have appreciable ultraviolet absorption but are effectively removed by an alkali wash.

\section{Standards}

The stock solution $(1 \mathrm{~g} / 1)$ :

Dissolve $10 \mathrm{mg}$ of phenobarbital in $0.5 \mathrm{ml}$ of $\mathrm{NaOH}(0.45 \mathrm{~mol} / \mathrm{l})$, and dilute to $10 \mathrm{ml}$ with Shrensen's phosphate buffer $(0.067$ $\mathrm{mol} / \mathrm{l}) \mathrm{pH} 7.4$.

Working phenobarbital standards $(10,20,30,50$ and $100 \mathrm{mg} / \mathrm{l})$ : Dilute $0.5,1.0,1.5,2.5$, and $5.0 \mathrm{ml}$ of the stock solution to $50 \mathrm{ml}$ with pooled drug-free serum or cerebrospinal fluid.

\section{Samples}

The blood samples were withdrawn by venous puncture and collected in glass tubes without addition of anticoagulants. The cerebrospinal fluid was obtained by lumbar puncture.

\section{Assay principle}

Phenobarbital in serum and cerebrospinal fluid is determined by extraction of the alkaline ( $\mathrm{pH} 13.0)$ and acidified ( $\mathrm{pH} 10.5)$ extract. The difference in absorbance between the $\mathrm{pH} 13.0$ and $\mathrm{pH} 10.5$ solutions at $260 \mathrm{~nm}$ is proportional to phenobarbital concentration in the sample (4).

\section{Assay procedure}

\section{Extraction}

A complete block diagram of the procedure is given in figure 1. A measured volume of the serum or cerebrospinal fluid $(2 \mathrm{ml}$ samples are taken) is transferred to a separating funnel, $25 \mathrm{ml}$ of previously purified dichloroethane is added, and the mixture shaken gently for 5 minutes. The aqueous (upper) phase is decanted off and the organic layer is transferred to another separating funnel. $3 \mathrm{ml}$ of $\mathrm{NaOH}(0.45 \mathrm{~mol} / \mathrm{l})$ are added, and' mixture shaken gently for 5 minutes. The organic (lower) phase is discarded, and the alkaline upper layer is drained to a centrifuge tube and centrifuged for 10 minutes at $2000 \mathrm{rpm}$. Any dichloroethane present will precipitate at the bottom and the supernatant is the alkaline extract. In none of the sera from the patients examined have we noted turbidity in the final alkaline extracts.

\section{Spectrophotometric measurement}

To each of two semimicro silica cells $1 \mathrm{ml}$ of the alkaline extract is transferred. To the reference cell $0.1 \mathrm{ml}$ of $\mathrm{NH}_{4} \mathrm{Cl}(300 \mathrm{~g} / \mathrm{l})$ is added. The same volume of $\mathrm{NaOH}(0.45 \mathrm{~mol} / \mathrm{l})$ is added to the sample cell, and the differential spectrum from 200 to $300 \mathrm{~nm}$ is recorded. When working without a recorder, the absorbance at $260 \mathrm{~nm}$ is measured.

\section{Quantitation}

The phenobarbital level was estimated by preparing a calibration curve with phenobarbital working serum or cerebrospinal fluid standards containing $10,20,30,50$ and $100 \mathrm{mg} / \mathrm{l}$.

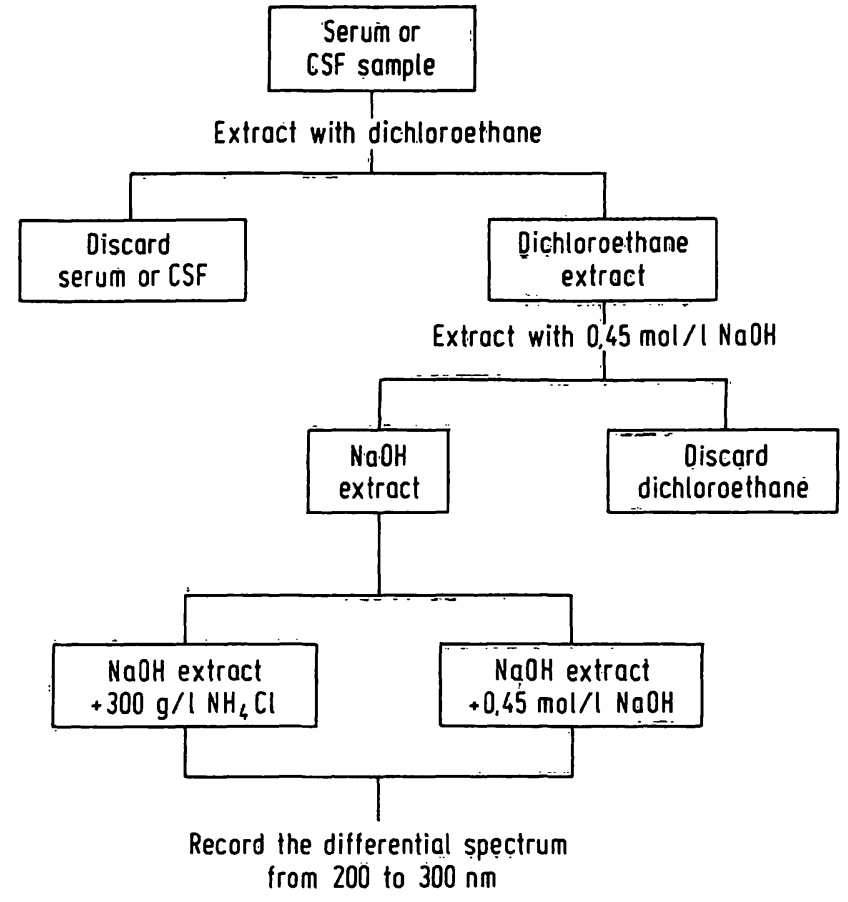

Fig. 1. Flow diagram of full procedure. $\mathrm{CSF}=$ Cerebrospinal fluid.

\section{Results}

Figure 2 shows the differential spectra of a number of concentrations of phenobarbital, obtained after extraction of sera or cerebrospinal fluid of patients treated with phenobarbital, methylphenobarbital and primidone. They all give a single peak at $260 \mathrm{~nm}$.

\section{Standard curve and bläks}

Figure 3 shows a phenobarbital calibration curve. The absorbance at $260 \mathrm{~nm}$ is linearly related to the phenobarbital concentrations over the range 1.0 to $100.0 \mathrm{mg} / \mathrm{l}$.

None of the blank serum and cerebrospinal fluid samples carried through the entire extraction procedure had peaks at $260 \mathrm{~nm}$.

\section{Recovery}

Recovery of phenobarbital was determined by comparing the absorbance at $260 \mathrm{~nm}$ of extracted standards with the absorbance at $260 \mathrm{~nm}$ obtained with an unextracted aqueous solution of phenobarbital $(20 \mathrm{mg} / \mathrm{l})$. After correction for aliquot factors, the actual recovery of phenobarbital from serum or cerebrospinal fluid was more than $90 \%$. The percentage recovery decreased when standards containing less than $10 \mathrm{mg} / 1$ were examined. 


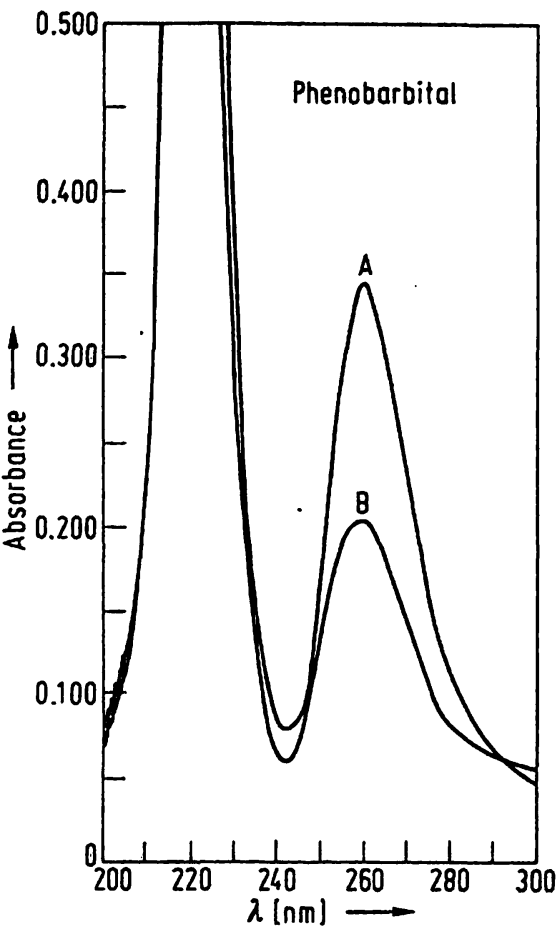

c

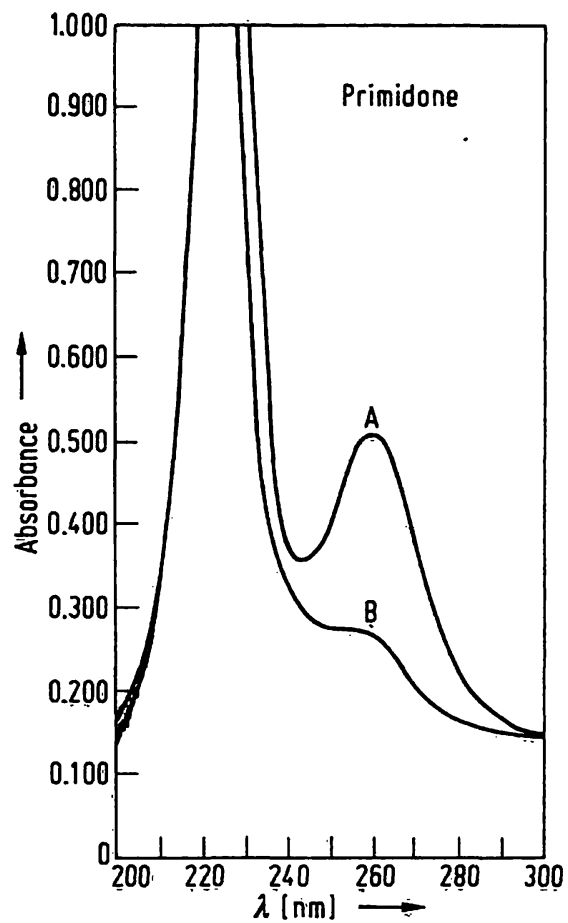

Fig. 2. a) Differential absorption spectrum of serum (A) of patient treated with phenobarbital $(3.3 \mathrm{mg} / \mathrm{kg}$ body weight). Differential absorption spectrum (B) of phenobarbital standard $(20 \mathrm{mg} / \mathrm{l})$.

b) Differential absorption spectra of serum (A) and cerebrospinal fluid (B) of patient treated with methylphenolbarbital (Phemiton, $5.17 \mathrm{mg} / \mathrm{kg}$ body weight): c)Differential absorption spectra of sera of patients treated with primidone (Mysoline):
(A) $25.0 \mathrm{mg} / \mathrm{kg}$ of body weight,

(B) $7.8 \mathrm{mg} / \mathrm{kg}$ of body weight. b
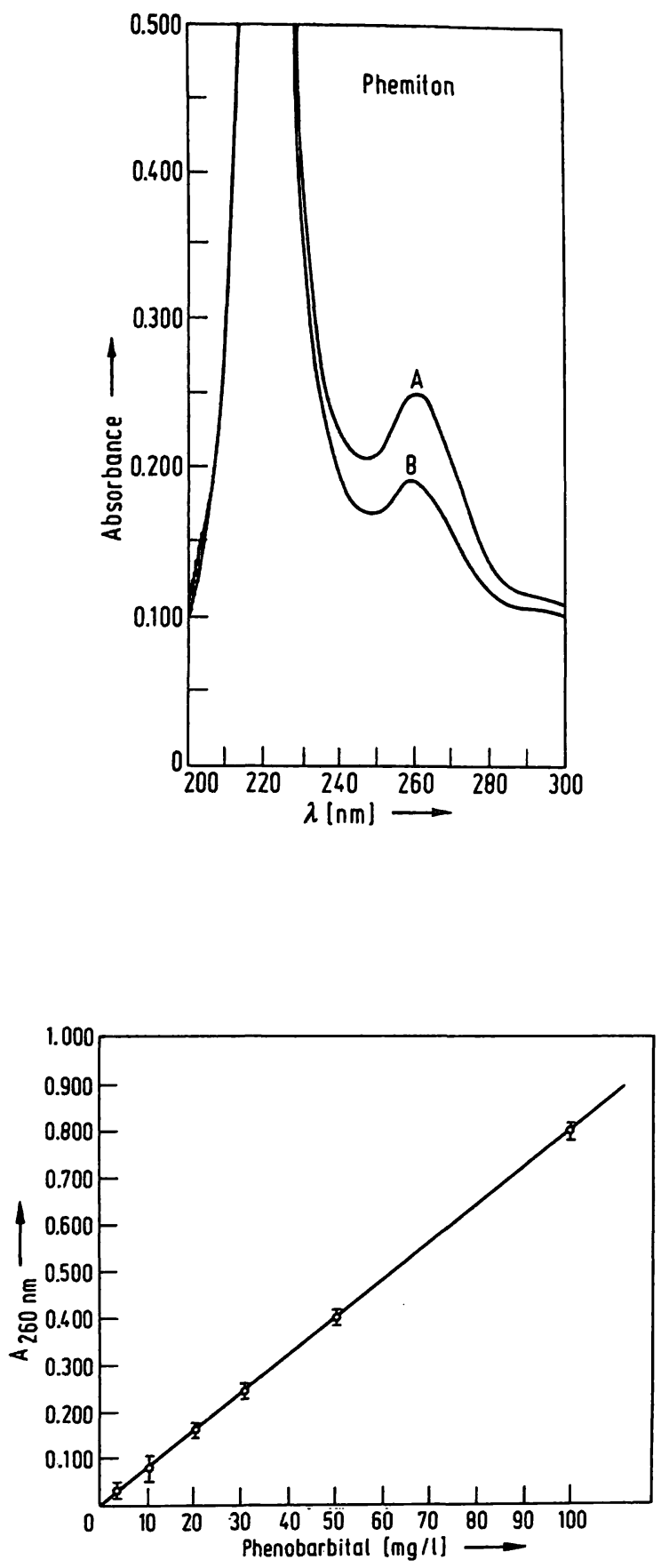

Fig. 3. Phenobarbital calibration curve. Absorbance was measured in a semimicro silica cells in a double-beam UV-spectrophotométer UNICAM SP 1800. Reference cell: $\mathrm{pH}$ 10.5; sample cell: $\mathrm{pH}$ 13.0. The points shown represent mean \pm 1 S.D.

\section{Sensitivity}

The practical limit of sensitivity for the method as described is $1.0 \mathrm{mg} / \mathrm{l}$ of phenobarbital in serum or cerebrospinal fluid.

\section{Precision}

The coefficient of variation obtained by extraction and analysis of eight replicate working standards $(20 \mathrm{mg} / \mathrm{l})$ 
was less than $1.5 \%$. Reproducibility did not vary significantly from day to day.

\section{Specificity of the assay}

The serum and cerebrospinal fluid samples from patients on antiepileptic treatment were analyzed as described above. The identity of the drug-related peaks was confirmed by the thin-layer chromatography. The $R_{F}$-values of phenobarbital extracted from sera and cerebrospinal fluid are identical to its respective standard. The serum extracts from patients treated with various drugs, such as: pyrithioxin (Encephabol), nitrazepam (Mogadon), methotrimeprazine maleate (Nozinan), biperiden hydrochloride (Akineton) and Meprobamate showed no peak at $260 \mathrm{~nm}$ when analyzed as described. To test the specifity of the assay against the common antiepileptic drugs, we prepared sera containing phenobarbital at a concentration of $20 \mathrm{mg} / 1$ and added one of the following antiepileptic drugs to each sample: diphenylhydantoin (Dilantin), carbamazepine (Tegretol), ethosuximide (Zarontin), Sulthiame (Ospolot), diazepam (Valium), barbital, butobarbital, amylobarbital. The samples were analyzed as described and we saw no interference in the assay, except for the 5,5-disubstituted barbiturates, which have the same differential spectra, there being small variations in the wavelengths of the absorption maxima. Since it is not recommended in the treatment of epileptic patients to combine two drugs with the same action and similar properties, such interference is of small practical importance.

\section{Discussion}

Over the past decade, clinicians have accepted the value of regular blood level measurements in antiepileptic drug therapy. Phenobarbital is one of the most frequently used antiepileptic drugs. Effective use of the drug depends on maintaining the proper blood concentration. Blood level measurements have become recognized as being valuable in adjusting and maintaining dosage schedules (1). Determination of serum level in a patient seen for the first time is also helpful. It gives an early and fair estimate of the reliability of the patient in taking his medications. The almost universal tendency of patients is that they are erratic in taking prescribed doses. The availability of serum levels allows better supervision of the actual doses taken, and makes it possible to significantly increase the serum levels in many patients whose original levels were low. The antiepileptic drug monitoring indicates which drug might reasonably be increased if seizures continue. The chronic use of these drugs in the therapy of epilepsy maximizes the probability that a potential toxicity will be realized. Drug monitoring suggest which drug is present in large amounts, and might be contributing to toxicity or might do so if the dose were raised.

A number of analytical methods for measuring phenobarbital blood levels are in use today and have been reviewed by Rose et al. (5). Although these methods are sensitive, they are time-consuming, difficult to perform and not routinely available. As a result, blood level measurements of antiepileptic drugs are not commonly used by clinicians treating seizure disorders. The choice of any analytical technique or method for the detection of antiepileptic drugs must take into consideration the purpose for which the analysis is performed, e. g. routine urine screening, toxicology, drug monitoring or hospital emergencies. Initially, quantitative serum measurements of antiepileptic drugs were attempted by colorimetric, ÚV-spectrophotometric and thin-layer chromatographic methods. More recently, gas liquid chromatography has become the most common analytical methodology (6). The thin-layer chromatographic procedures are not truly quantitative; they are principally advantageous for toxicity screening tests. While gas liquid chromatography is sensitive and accurate (if performed properly) the method is complex, timeconsuming and quite sensitive to operator skill and sample preparatory procedures. As a result, serum drug measurements with gas liquid chromatography are often inconsistent and unreliable. Several UV-methods are available for the analysis of barbiturates in serum or urine. They all usually have one characteristic in common, i. e. that of being rather laborious and time:consuming $(4,7,8,9)$.

When devising the principle described here, the intention was to devise a method for analysis involving as few manipulations and reagents as possible, yet giving clinically fully acceptable results. The basis for our procedure is Goldbaum's method (4) which we improved with several modifications, including a single extraction technique with dichloroethane; this has resulted in a very simple yet accurate method. The whole analysis takes less than 20 minutes. One of the most serious complications of direct solvent extraction methods is the formation of emulsions. We found that chloroform is worse than dichloroethane in this respect. A good general rule is to ensure that the solvent volume is much larger than the sample volume. In our method we found a ratio of 12.5:1 to be the most suitable. We used $\mathrm{NH}_{4} \mathrm{Cl}(300 \mathrm{~g} / \mathrm{l})$ for adjusting the $\mathrm{pH}$ to 10.5 in a reference cuvette, instead of boric acid- $\mathrm{KCl}$ solution, since this eliminates the crystallization at room temperature.

Immunoassay techniques (Radioímmunoassay and Enzyme Multiplied Immunoassay Technique) are more effective in detecting barbiturates than is the spectrophotometric technique or the gas-chromatographic technique. They are more rapid, and therefore convenient for screening purposes. Enzyme immunoassay now enables nearly any laboratory to perform fast, 
convenient, quantitative serum determinations of the drug. Five different antiepileptic drugs can be assayed from one $50 \mu \mathrm{l}$ serum sample prepared from a "finger stick" blood specimen. However, the lack of specifity exhibited by the immunoassay methods and high price of reagents are a distinct disadvantage (10). Severe hemolytic, lipemic or icteric samples may cause poor reproducibility and questionable quantitation when immunochemical methodology is used (10). With our method, addition of known concentrations of phenobarbital to highly lipemic or severe hemolytic sera resulted in absorbance curves that were identical to those for the corresponding standards.

\section{References}

1. Buchthal, F. \& Lennox-Buchthal, M. A. (1972), in Antiepileptic Drugs (Woodbury, D. M., Penry, J. K. \& Schmidt, R. P. eds.), Raven Press Publishers, New York, pp. 335-343.

2. Maynert, E. W. (1972), in 1. c. (1), pp. 311-317.

3. Gallagher, B. B. \& Baumel, 1. P. (1972), in 1. c. (1), pp. 361 -366 .

4. Goldbaum, L. R. (1952), Anal. Chem., 24, 1604.

5. Rose, S. W., Smith, L. D., \& Penry, J. K. (1974), NINDSNIH-PHS-HEW, Washington, D. C.
6. Kupferberg, H. J. (1970), Clin. Chim. Acta, 29, 283-288.

7. Lous, P. (1954), Acta Pharmacol. Toxicol., 10, 134-146.

8. Broughton, P. M. G. (1956), Biochem. J., 63, 207-213.

9. Dain, D. W. \& Trainer, T. D. (1970), Clin. Chem., 16, 318-321.

10. Mulé, S. J., Bastos, M. L. \& Jukofsky, D. (1974), Clin. Chem., 20, 243-248.
Vera Jeremić, M. D., M. Sc., Neuropsychiatric Clinic University of Novi Sad YU-21000 Novi Sad 
